\title{
Cultivation of Erianthus and Napier Grass at an Abandoned Mine in Lampung, Indonesia
}

\author{
Nobuhito Sekiya1 ${ }^{*}$, Jun Abe ${ }^{2,3}$, Fumitaka Shiotsu4, Shigenori Morita1,5 \\ ${ }^{1}$ Institute for Sustainable Agro-Ecosystem Services (ISAS), Graduate School of Agricultural and Life Sciences, \\ The University of Tokyo, Tokyo, Japan \\ ${ }^{2}$ Department of Agricultural and Environmental Biology, Graduate School of Agricultural and Life Sciences, The \\ University of Tokyo, Tokyo, Japan \\ ${ }^{3}$ Department of Plant Science, School of Agriculture, Tokai University, Kumamoto, Japan \\ ${ }^{4}$ College of Agriculture, Ibaraki University, Ibaraki, Japan \\ ${ }^{5}$ Department of Agriculture, Faculty of Agriculture, Tokyo University of Agriculture, Kanagawa, Japan \\ Email: ${ }^{*}$ kapinivilage@yahoo.co.jp
}

Received 9 April 2014; revised 8 May 2014; accepted 20 May 2014

Copyright () 2014 by authors and Scientific Research Publishing Inc.

This work is licensed under the Creative Commons Attribution International License (CC BY).

http://creativecommons.org/licenses/by/4.0/

(c) (i) 0pen Access

\section{Abstract}

The production of cellulosic bioethanol from non-edible plants is drawing increasing attention, as it potentially avoids food-fuel competition. Because growing such plants on farmland indirectly reduces food availability, the plants should be grown on marginal, non-arable lands. In this study, we evaluated the growth of cellulosic energy crops at a former mining site in Indonesia. This mine was abandoned because it contained few mineral deposits, and exposed subsoils rather than toxic soils prevented revegetation. In the first trial, growths of two energy plant species Erianthus spp. and Napier grass (Pennisetum purpureum) were compared with that of maize (Zea mays) at the mine site and a nearby degraded farm. Erianthus and Napier grass produced 11.7 and $22.5 \mathrm{t} \cdot \mathrm{ha}^{-1}$ of shoot dry matter at 8 months after planting (MAP) in the farm respectively while maize plants failed to establish, but none of the three species grew at the mine. In the second trial, two-weekold seedlings of Erianthus and Napier grass rather than stem cuttings as used in the first trial were planted at the mine site. Erianthus and Napier grass produced 16.3 and $24.0 \mathrm{t} \cdot \mathrm{ha}^{-1}$ of shoot dry matter over the course of 18 months, respectively. Application of organic fertilizer significantly increased shoot dry matter to 18.9 and $39.6 \mathrm{t} \cdot \mathrm{ha}^{-1}$ in Erianthus and Napier grass, respectively. During the 18-month growth period, both of the energy plants significantly increased soil carbon at the $0-0.3 \mathrm{~m}$ depth from $0.33 \%$ to $1.15 \%-1.23 \%$ when chemical fertilizer was applied and to $0.67 \%-0.69 \%$ when both chemical and organic fertilizers were applied. From 0 - 5 MAP, soil surface level dropped by $28.0-34.7 \mathrm{~mm}$ in plots without plants due to soil erosion. In contrast, both of the energy plants significantly reduced the drop of soil surface level to $16.0-19.3 \mathrm{~mm}$ in plots with chemical fertilizer alone and to $18.0-20.7 \mathrm{~mm}$ in plots with chemical and organic fertilizers.

*Corresponding author. 
Proportions of small soil particles, that would be easily detached and transported by water flow compared with large particles, were larger in the planted plots than the no-plant plots at 16 MAP. The results suggest that successful cultivation of energy plants on abandoned mine sites is possible, particularly if seedlings are transplanted and the crops are fertilized with organic fertilizer. In addition, the cultivation of Erianthus and Napier grass has positive impacts on soil quality that may contribute to their sustainability as crops and to the conservation of the local ecosystem.

\section{Keywords}

Biomass, Cellulosic Energy Crops, Unused Land, Subsurface Soils

\section{Introduction}

Bioethanol is a promising alternative to fossil fuels and is viewed as a potential countermeasure to global warming. However, there are concerns that the cultivation of food crops for consumption is sacrificed for bioethanol production, leading to global food insecurity [1]. Therefore, producing cellulosic bioethanol from nonedible plants is receiving increasing attention [2]. To avoid conflicts with food crop production, it is recommended that non-edible plants be cultivated on marginal lands such as agriculturally degraded lands [3], abandoned agricultural lands [4]-[6], and degraded or waste lands [6] [7]. Some trials have been conducted on such lands to examine the feasibility of their use [8]-[12].

In Japan, a number of projects have been implemented to establish a national bioethanol industry [13] [14]. Our project called as "The Development of Technology for High-Efficiency Conversion of Biomass and Other Energy" aims to avoid food-fuel competition by producing cellulosic bioethanol on marginal lands [15]. One challenge is that there may be no marginal lands with favorable climatic conditions for plant growth in Japan. In addition, the cost of producing bioethanol is estimated to be much higher in Japan than the cost of buying imported bioethanol, due to the high value of land [14] [16]. Under these circumstances, the government has defined imported bioethanol that was produced in Asian countries using Japanese technologies to be a "quasi-domestic product” [14]. Our research group identified Lampung province in Indonesia as a potential site for the production of cellulosic energy plants [17].

Unused lands with high net primary production cover a large area within Lampung province. Field surveys revealed that various types of unused lands exist in the province, including abandoned small-scale mining sites. Those sites were abandoned mostly because few mineral deposits were found there after initial prospecting. Thus, unlike many mining sites in Indonesia that have been contaminated with toxic elements such as mercury [18]-[20], the exposure of deep subsoils prevents either revegetation or farming, rendering those sites idle and vulnerable to soil erosion. If cellulosic energy plants could be grown there, raw materials for bioethanol would be produced without interfering with the production of food crops, at the same time possibly conserving the local ecosystem by reducing soil erosion.

We investigated the possibility of converting abandoned mining sites into energy plant fields. In our previous work, we selected Erianthus (Erianthus spp.) and Napier grass (Pennisetum purpureum) as energy plants because they produced large amounts of shoot biomass in tropical and subtropical climates, and because they tolerated biotic and abiotic stresses well [2] [21] [22].

\section{Material and Methods}

\subsection{Site Description}

Trials were conducted at an abandoned small-scale mining site in Sabah Balau village, Tanjung Bintang district, Lampung province, Indonesia $\left(5^{\circ} 40^{\prime} \mathrm{S}, 105^{\circ} 32^{\prime} \mathrm{E}\right)$. The climate is humid tropics. The rainfall pattern is greatly affected by the tropical monsoon system in which the rainy season lasts from October to May and the dry season lasts from June to September (e.g. the annual rainfall was 1,338 $\mathrm{mm}$ in 2012), although there were unusually frequent rainfalls and no distinct dry period in 2013 (Figure 1). The temperature is high (e.g. the annual mean temperature was $27.9^{\circ} \mathrm{C}$ in 2012) and stable year round. Soil characteristics in this area were previously described in detail [23]; the reddish-grey surface horizon has clayey texture (68\% - $92 \%$ in soil at $0-0.35 \mathrm{~m}$ depth) with very friable consistency. The homogenous, yellowish-red subsurface horizons also have clayey texture with 


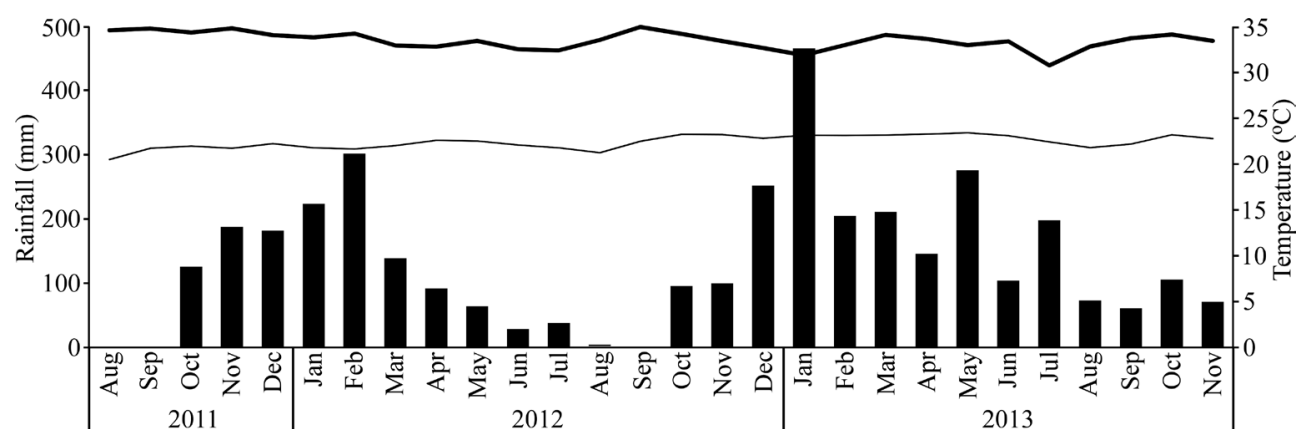

Figure 1. Monthly rainfall (bar) and monthly mean temperature (maximum, thick line; minimum, thin line) throughout the study period.

friable consistency and subangular blocky structure. They are classified as oxic horizons with low concentrations of phosphorus (120 - $\left.140 \mathrm{mg} \cdot \mathrm{kg}^{-1}\right)$ and potassium $\left(20-40 \mathrm{mg} \cdot \mathrm{kg}^{-1}\right)$, low availability of water pores $(9.2 \%$, vol.), and low cation-exchange capacity $\left(1.9-2.8 \mathrm{cmol} \cdot \mathrm{kg}^{-1}\right)$. The trial site was prospected in 2007 but abandoned because of the lack of mineral deposits, especially iron. As a result, nearly a quarter hectare of gently sloping, subsurface horizons (2.0 - $3.0 \mathrm{~m}$ in depth) was left exposed. Prior to this study, no plant was growing in the site, whereas neighboring land was covered with grasses and shrubs.

\subsection{First trial}

The exposed subsoils at the mine site were plowed to a depth of 0.15 - $0.20 \mathrm{~m}$ with a two-wheel, 30-horsepower hand-tractor from July 25 to July 29, 2011. On August 2, 2011, stem cuttings of Erianthus were planted at a spacing of $2 \times 1 \mathrm{~m}$ between hills in a plot measuring $8 \times 13 \mathrm{~m}$, and stem cuttings of Napier grass were planted at a spacing of $1 \times 0.5 \mathrm{~m}$ between hills in a plot measuring $8 \times 4 \mathrm{~m}$. The two species were suggested by previous works to produce large shoot biomass when planted at those spacings, e.g. [22]. For comparison, maize (Zea mays) seeds were sown at a spacing of $0.75 \times 0.25 \mathrm{~m}$ between hills in a plot measuring $8 \times 4 \mathrm{~m}$ on the same day. Those three plots were randomly arranged and replicated three times (randomized complete block design).

Plots were also established in a degraded farm $20 \mathrm{~m}$ down the slope. This field was once covered with grasses but was converted to a banana field in 2007. After two years of banana production, the field was planted with cassava until our study began. Land preparation, planting, and plot arrangements were carried out the same way as in the mining site. Chemical fertilizer was applied in the amounts of $30 \mathrm{~kg} \cdot \mathrm{N} \cdot \mathrm{ha}^{-1}, 15 \mathrm{~kg} \mathrm{P}_{2} \mathrm{O}_{5} \mathrm{ha}^{-1}$, and $15 \mathrm{~kg}$ $\mathrm{K}_{2} \mathrm{O} \cdot \mathrm{ha}^{-1}$ in each plot, at $0,1.5$, and 3 months after planting (MAP).

Unlike previous years, this period in 2011 was very dry and received no rainfall from July 25 to October 6 (Figure 1). All the plots were irrigated during dry spells until December 30, 2011 (Table 1). Missing hills were replanted at 1 MAP. Maize plants were harvested at 3.5 MAP (November 2011), and Erianthus and Napier grass plants were harvested at 8 MAP (March 2012). Fresh matter from each plot was weighed on-site. Subsamples were extracted from each plot, brought back to the laboratory of P.T. TOYOTA BIO INDONESIA (TBI), ovendried at $80^{\circ} \mathrm{C}$ for at least $72 \mathrm{~h}$, and weighed. The weight ratios of dry to fresh matter of each subsample were used to calculate the dry matter weights of whole plants in each plot.

\subsection{Second Trial}

Plant residues from the mining site, including roots, in surface soil layers (0 - $0.15 \mathrm{~m}$ in depth) were removed from April 23 to April 27, 2012. Soil cores (diameter, $50 \mathrm{~mm}$; length, $300 \mathrm{~mm}$ ) were collected from 6 representative positions within the mining site, by inserting a liner sampler DIK-110C (Daiki Rika Kogyo, Saitama, Japan) at a right angle to the soil surface. Each of the six soil cores was dried in the shade and stored in a paper bag for subsequent soil analyses as described below. Plowing was omitted in this trial.

On May 1, 2012, 600 Erianthus and 600 Napier grass stem cuttings were planted, each in a $3.0 \mathrm{~L}$ vinyl pot filled with topsoil. The pots were placed in the TBI experimental field, irrigated every day, and transferred to the mining site on May 15, 2012. The seedlings were transplanted at a narrow spacing of $0.5 \times 0.5 \mathrm{~m}$ between hills compared with those spacings in the first trial in an attempt to enhance the early establishment of plant community in plots measuring $5 \times 4 \mathrm{~m}$ for each species ( $\mathrm{Er}$ and $\mathrm{Na}$ ). A plot without plants was also prepared to serve as the control (No). 
Table 1. Amount of water (mm) supplied to each plot between planting and harvesting in the first trial, and between planting and the first mowing in the second trial. Supplemental irrigation was provided in the first trial, and no additional water was supplied in the second trial.

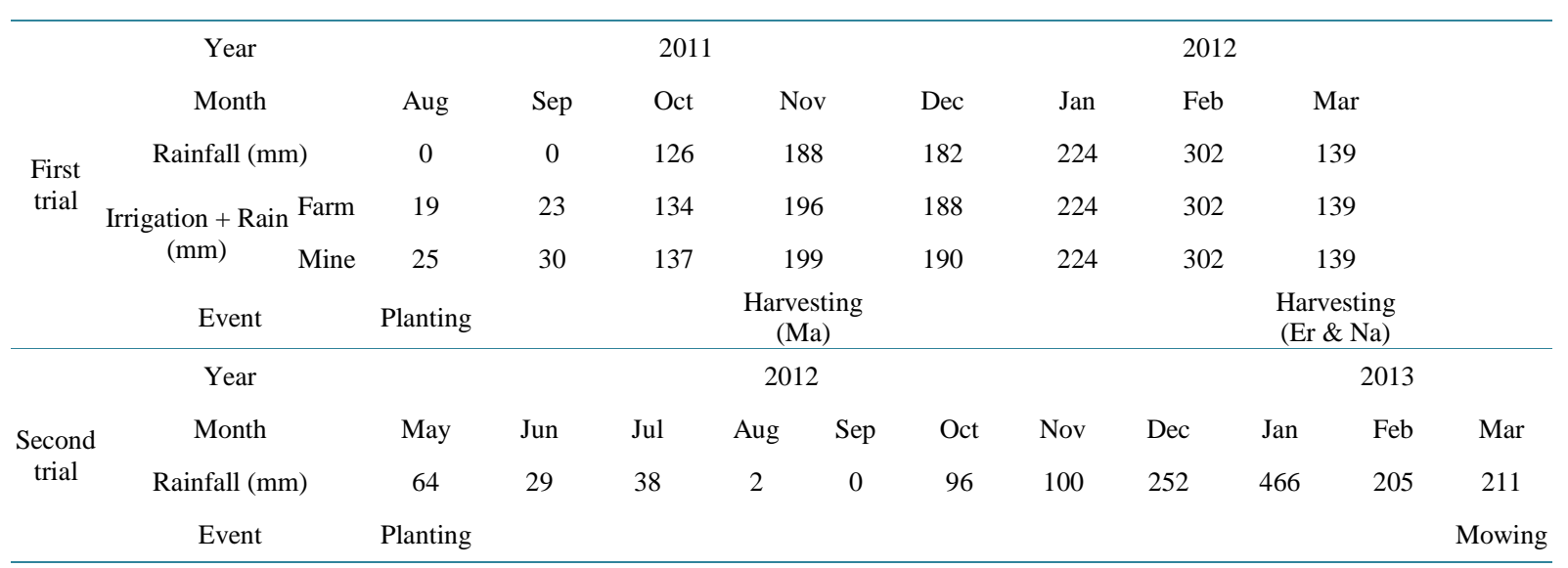

Farm $=$ the degraded farm, Mine = the abandoned mining site, $\mathrm{Ma}=$ maize, $\mathrm{Er}=$ Erianthus, $\mathrm{Na}=$ Napier grass.

These three plots were subjected to a chemical fertilizer (C) treatment. Another set of three plots was also established and subjected to a chemical and organic fertilizer (CO) treatment. In both the $\mathrm{C}$ and CO treatments, chemical fertilizer was applied at the same rate as above: 0, 1.5, and 3 months after transplanting (MAT). Because plants were mowed in order to weigh the dry matter they produced a few times before they were harvested, chemical fertilizer was again applied to the plots at the same rate as above: $0,1.5$, and 3 months after mowing. In the CO treatment, air-dried cattle manure obtained from a nearby beef company was applied in the amounts of $20 \mathrm{t} \cdot \mathrm{ha}^{-1}$ and $10 \mathrm{t} \cdot \mathrm{ha}^{-1}$ immediately after transplanting and mowing, respectively.

In order to trace the soil surface level, a steel bar (diameter, $8 \mathrm{~mm}$; length, $1.5 \mathrm{~m}$ ) was inserted at five representative positions in each plot at a right angle to the soil surface, to a depth of $0.2 \mathrm{~m}$. These six plots were randomly arranged and replicated three times (randomized complete block design). Unlike in the first trial, the period of seedling establishment in 2012 experienced occasional rainfalls (Figure 1), so no irrigation was applied. Missing hills were replanted at 1 MAT, and weeds were removed by spraying herbicide at 3 (Glufosinate) and 5 MAT (Paraquat). The steel bars were often stolen during the course of the study. Therefore, we abandoned this method and instead measured weight proportions of different soil particle sizes. In general, the smaller the particle size, the more easily soils can be detached and transported by water flow [24]. We expected that a greater proportion of small particles would be found in the planted plots than in the no-plant ones as a result of reduced water flow. Small soil cores (diameter, $50 \mathrm{~mm}$; length, $10 \mathrm{~mm}$ ) were collected from two representative positions in each plot under the $\mathrm{C}$ treatment at 16MAT, by inserting a stainless steel cylinder at a right angle to the soil surface. Each soil core was oven-dried at $80^{\circ} \mathrm{C}$ for at least $24 \mathrm{~h}$ and the cores were divided into five classes by particle size ( 0 - $0.5 \mathrm{~mm}, 0.5$ - $1 \mathrm{~mm}, 1-2 \mathrm{~mm}, 2$ - $4 \mathrm{~mm},>4 \mathrm{~mm}$ ) using sieves. Then, soils of each class were weighed to determine the weight proportions of each class in each soil core.

Larger soil cores (diameter, $50 \mathrm{~mm}$; length, $300 \mathrm{~mm}$ ) were collected from five other positions in each plot by inserting the liner sampler as described above at 18 MAT, after which the cores were mixed together and dried in the shade. All the soil samples, including those collected before the trial, were sent for analysis to the Department of Soil Science and Land Resources of Bogor Agricultural University. Total carbon and total nitrogen in each sample were determined by using a CHNS analyzer TruSpec Micro (LECO Corporation, St. Joseph, USA).

The dry matter weight of Erianthus samples was determined as described above at 10 (March 2013) and 18 MAT (November 2013), and those of Napier grass were determined at 10, 14 (July 2013), and 18 MAT.

Larger soil cores (diameter, $50 \mathrm{~mm}$; length, $300 \mathrm{~mm}$ ) were again collected from four other positions in each plot by inserting the liner sampler as described above at 19 MAT (December 2013). Roots were gently washed out of soil cores under running water until free of soil using a $0.5-\mathrm{mm}$ sieve, oven-dried at $80^{\circ} \mathrm{C}$ for at least $72 \mathrm{~h}$, and weighed. A soil profile (1 - $2 \mathrm{~m}$ long $\times 2 \mathrm{~m}$ deep) was exposed in one of the Erianthus plots and another in Napier grassplots by digging a trench $(1-2 \mathrm{~m}$ long $\times 1 \mathrm{~m}$ wide $\times 2 \mathrm{~m}$ deep) manually. A larger soil core $(50 \mathrm{~mm}$ diameter $\times 600 \mathrm{~mm}$ long) was then collected from the bottom of the trench by inserting the liner sampler as described above. Roots were gently washed out of soil cores under running water until free of soil using a 0.5-mm 
sieve.

\section{Results and Discussion}

\subsection{Water Supply and Plant Growth}

Table 1 shows the amount of water that the plots received in the two trials, including irrigation water and rainfall. There was a distinct difference between the two trials in the amount of rainfall during the period of plant establishment. There was no rainfall during the period of plant establishment in the first trial, which was August, but during the same period in the second trial, which was May, the plot received $64 \mathrm{~mm}$ of rainfall. In the first trial, therefore, the degraded farm (Farm) and mining site (Mine) were irrigated with 19 and 25 mm of water in August, respectively.

However, those amounts of irrigation water appeared insufficient to enhance the growth of maize, Erianthus, and Napier grass; their mortality rates at 1 MAP calculated by dividing the number of wilted plants by the total number of plants in each plot were $24.1 \%, 26.2 \%-31.7 \%$, and $15.9 \%-28.6 \%$, respectively. As there was no rainfall even in September in the first trial, the Farm and Mine were again irrigated with $23 \mathrm{~mm}$ and $30 \mathrm{~mm}$ of water, respectively. To further support plant growth even after the onset of rainy season, the Farm and Mine were irrigated with $22(8+8+6) \mathrm{mm}$ and $30(11+11+8) \mathrm{mm}$ of water from October to December, respectively. The Farm and Mine received $1225 \mathrm{~mm}$ and $1246 \mathrm{~mm}$ of rainfall and irrigation water combined throughout the experimental period, respectively. Despite the amount of water that they received, the three species exhibited little plant growth in the Mine; plant lengths at harvest were $0.25 \mathrm{~m}, 1.27 \mathrm{~m}$ and $1.34 \mathrm{~m}$ in maize, Erianthus, and Napier grass, respectively. In the Farm, however, Erianthus and Napier grass grew well to $2.45 \mathrm{~m}$ and $3.57 \mathrm{~m}$ in plant length respectively, although the maize did not (0.53 $\mathrm{m}$ in plant length).

In contrast, in the second trial, in which two-week-old Erianthus and Napier grass seedlings were transplanted, both species established well in the Mine. The difference in plant growth at planting time appeared to favor seedling establishment in the second trial. Presumably, the roots of transplanted seedlings had better access to rainwater that fell during the establishment period. The mortality rates of $6.3 \%-7.1 \%$ for Erianthus and $5.0 \%$ $7.1 \%$ for Napier grass were well below those recorded in the first trial. Both species continued to grow well from 2 to 7 MAP (June - November), even though the amount of water supply (entirely from rainfall) was well below the amount received during the same period (September-February) in the first trial.

\subsection{Shoot Dry Matter}

The shoot dry matter weights of each plant species, for both trials, are shown in Figure 2. In the first trial, maize wilted after 4 - 6 leaves developed and produced only $0.83 \mathrm{t} \cdot \mathrm{ha}^{-1}$ of shoot dry matter in the Farm (Figure 2(a)). In addition to the degraded soil, water deficit during the period of plant establishment contributed to the low biomass yield (Table 1). In contrast with maize, Erianthus and Napier grass produced 11.7 and $22.5 \mathrm{t} \cdot \mathrm{ha}^{-1} \mathrm{of}^{\mathrm{s}}$ shoot dry matter in the Farm, respectively (Figure 2(a)). These results suggest that the two species are capable of growing vigorously under environmental conditions that severely limit the growth of maize.

In the Mine, however, none of the three species performed well. Shoot dry matter weights of maize, Erianthus, and Napier grass were 0.02, 0.07, and $1.55 \mathrm{t} \cdot \mathrm{ha}^{-1}$, respectively (Figure 2(b)). The environmental conditions in the Mine was so challenging that even the Erianthus and Napier grass, which overcame the environmental conditions of the Farm, did not grow well. Because the Mine was only $20 \mathrm{~m}$ away from the Farm, it experienced the same climatic conditions, such as rainfall, temperature, light, and humidity. The two sites differed only in the presence of surface soils in the Farm and the exposure of subsoils in the Mine. Thus, the poor performances of Erianthus and Napier grass in the Mine are ascribed to the absence of surface soils and/or the exposure of subsoils. As described, the two locations received almost the same amount of water throughout the experimental period (Table 1). However, some of the water supplied to the Mine was observed to have frequently run off the soil surface rather than infiltrating it. Subsoils in this area are known for their poor water-holding characteristics [23]. Therefore, the exposed subsoils might have limited growth of Erianthus and Napier grass by reducing the amount of water available to them.

In the second trial, both Erianthus and Napier grass performed well, even in the Mine. At 10 MAP, shoot dry

matter weights of Erianthus and Napier grass that had received chemical fertilizer were 6.5 and $9.5 \mathrm{t} \cdot \mathrm{ha}^{-1}$, respectively (Figure 2(c)). When they were treated with organic fertilizer (manure), Erianthus and Napier grass 
increased their shoot dry matter weights to 8.7 and $18.8 \mathrm{t} \cdot \mathrm{ha}^{-1}$, respectively (Figure 2(c)). From 10 to 18 MAP, regenerated Erianthus and Napier grass plants that received chemical fertilizer produced 9.8 and $14.5 \mathrm{t} \cdot \mathrm{ha}^{-1}$ of shoot dry matter, respectively (Figure 2(d)). The addition of organic fertilizer increased shoot dry matter to 11.9 and $20.8 \mathrm{t} \cdot \mathrm{ha}^{-1}$ in Erianthus and Napier grass, respectively (Figure 2(d)). Two-way ANOVA with repeated measures on treatment (C-Er, C-Na, CO-Er, and CO-Na) and time (10 and $18 \mathrm{MAP}$ ) revealed that the both effects were significant at the $1 \%$ level with no significant interaction. In the second trial, Napier grass produced a greater amount of shoot dry matter than did Erianthus, and the dry matter increased with the addition of organic fertilizer. Plants in all the treatment groups produced more shoot dry matter at 18 MAP than at 10 MAP. These results suggest that the use of 2-week-old seedlings greatly improves the plants' performances, as does the use of organic fertilizer. The increase in shoot dry matter from 10 to 18 MAP suggests that a prolonged cropping period may further increase productivity.

\subsection{Soil Carbon and Erosion}

In the second trial, the effect of plant growth on soil carbon at 18 MAP was also investigated (Table 2). The total amounts of carbon measured prior to the second trial (No-Pre) were $0.33 \%$ and $0.32 \%$ at depths of $0-0.3 \mathrm{~m}$ and $0.3-0.6 \mathrm{~m}$, respectively. The total carbon amount remained almost the same when the plot was left for 18 months without planting (No).

In contrast, the total carbon amount at the $0-0.3 \mathrm{~m}$ depth increased to $1.15 \%-1.23 \%$ when chemical fertilizer was applied and to $0.67 \%-0.69 \%$ when both chemical and organic fertilizers were applied. Two-way ANOVA using plants (No, Er, and $\mathrm{Na}$ ) and fertilizer (C and $\mathrm{CO}$ ) as main effects revealed that both effects were significant at the $1 \%$ level with no significant interaction. At a depth of $0.3-0.6 \mathrm{~m}$, however, no significant

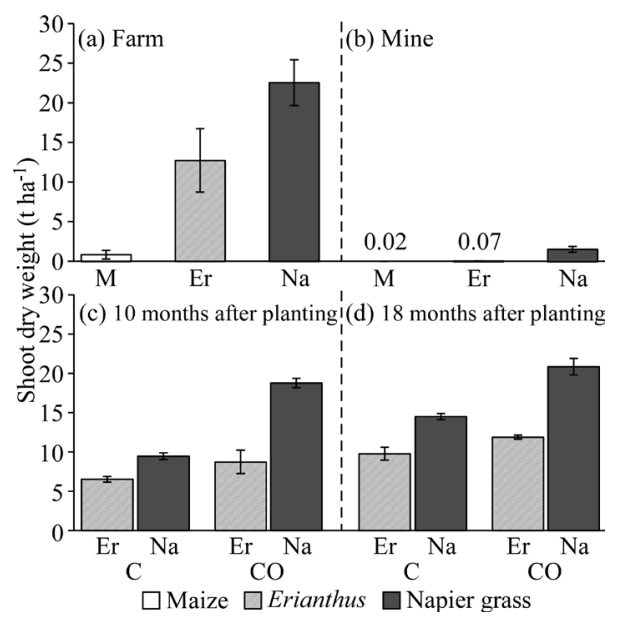

Figure 2. Shoot dry matter weight $\left(\mathrm{t} \cdot \mathrm{ha}^{-1}\right)$ of plants grown in the first (a, b) and second (c, d) trials. Each bar represents a mean \pm S.E. $(n=3)$. Farm= the degraded farm, Mine $=$ the abandoned mining site, $\mathrm{Ma}=$ maize, $\mathrm{Er}=$ Erianthus, $\mathrm{Na}=$ Napier grass, $\mathrm{C}=$ chemical fertilizer alone, $\mathrm{CO}=$ chemical and organic fertilizers combined.

Table 2. Soil total carbon (\%) in soil layers at depths of $0-0.3 \mathrm{~m}$ and $0.3-0.6 \mathrm{~m}$ measured 18 months after planting in the second trial.

\begin{tabular}{ccccccccc}
\hline & & \multicolumn{3}{c}{ C } & \multicolumn{3}{c}{ CO } \\
\cline { 3 - 8 } Depth & No-Pre & No & Er & Na & No & Er & Na \\
\hline $0-0.3 \mathrm{~m}$ & 0.33 & 0.48 & 1.15 & 1.23 & 0.28 & 0.67 & 0.69 \\
$0.3-0.6 \mathrm{~m}$ & 0.32 & 0.42 & 0.38 & 0.37 & 0.17 & 0.30 & 0.34 \\
\hline
\end{tabular}

No-Pre = Before trial (no plant), No = No plant, Er = Erianthus, $\mathrm{Na}=$ Napier grass, $\mathrm{C}=$ chemical fertilizer alone, $\mathrm{CO}=$ chemical and organic fertilizers combined. 
effects were detected. These results suggest that the 18-month plant growth significantly increases the amount of total carbon in soil at $0-0.3 \mathrm{~m}$ depth. Interestingly, the addition of organic fertilizer reduces the total carbon in the same layer. This effect of organic fertilizer on soil carbon requires further study.

Because no organic matter was added to the plots that received chemical fertilizer alone, the increased soil carbon in those plots should be solely ascribed to the decomposition of plant material. During the 18-month growth period, plant litter was seldom observed on the soil surface, and the entire aboveground biomass was collected during mowing or harvesting. Therefore, we assume that plant roots were the main source of increased soil carbon. During food crop production, the incorporation of plant residue into soils after harvesting is known to contribute greatly to the maintenance of soil fertility. In the case of energy plant production, however, the entire aboveground biomass is harvested. Some studies have pointed out that this harvesting practice could reduce soil fertility and eventually threaten the sustainability of the production system [25] [26]. Lemus and Lal (2005) [27] argue that the removal of the aboveground biomass of energy plants might have little influence on soil organic carbon (SOC) due to the plants' large belowground biomass. Indeed, switchgrass increased SOC several years after it was established [28], due to its large root system [29]. In our previous report, we argued that Erianthus and Napier grass may positively affect SOC because they develop large and deep root systems [30]. The results of the second trial in the present study should support our claim, although prolonged monitoring is necessary in order to draw a certain conclusion.

The effect of plant growth on soil surface level was also investigated in the second trial (Figure 3(a)). When the plots were left without being planted for 5 months, the soil surface level dropped by $34.7 \mathrm{~mm}$ in plots that received chemical fertilizer alone and $28.0 \mathrm{~mm}$ in plots that received both chemical and organic fertilizers. In contrast, in plots that were planted, the soil surface level dropped by 16.0 - $19.3 \mathrm{~mm}$ in plots that received chemical fertilizer alone and $18.0-20.7 \mathrm{~mm}$ in plots that received both types of fertilizers. The two-way ANOVA using plants (No, Er, and $\mathrm{Na}$ ) and fertilizer (C and $\mathrm{CO}$ ) as main effects revealed that only the effect of plants was significant at the $5 \%$ level, with no significant effects for fertilizer or their interactions. Surface runoff was frequently observed after rainfall events during both trials. Gully erosion even occurred near the trial site where water coursed down from the higher slopes. Thus, the drop in the soil surface level should be ascribed to soil erosion caused by rainwater.

The weight proportions of different soil particle classes were $34.1 \%$ - 35.6\% (for particle sizes of 0 - $0.5 \mathrm{~mm}$ ), $14.5 \%$ - 15.5\% (0.5 - $1.0 \mathrm{~mm}$ ), $11.5 \%$ - 12.1\% (1.0 - $2.0 \mathrm{~mm}$ ), 13.0\% - 14.9\% (2.0 - $4.0 \mathrm{~mm}$ ), and $24.3 \%$ - 24.4\% $(>4.0 \mathrm{~mm}$ ), and were similar in Erianthus and Napier grass (Figure 3(b)). In contrast, in the no-plant plots, the proportion at $0-0.5 \mathrm{~mm}$ was only $22.7 \%$ and that in the $>4.0 \mathrm{~mm}$ class was $46.8 \%$. These results agreed with our expectation that the proportion of small soil particles in the $0-0.5 \mathrm{~mm}$ class would be larger in the planted plots, and that the proportion of large soil particles in the $>4.0 \mathrm{~mm}$ class would be larger in the no-plant plots.

The measurements of soil surface level and the proportions of soil particle sizes suggest that Erianthus and Napier grass effectively reduced soil erosion. The absorption of rainfall energy by their plant canopies was probably an important aspect of their reduction of soil erosion. The soil core sampling revealed that Erianthus and Napier grass possessed $255-274 \mathrm{~g} \cdot \mathrm{m}^{-2}$ and $83-138 \mathrm{~g} \cdot \mathrm{m}^{-2}$ of roots at harvest, respectively. We also confirmed by digging trenches that the roots of the two species penetrated to at least a depth of $2.6 \mathrm{~m}$ (Figure 4). As

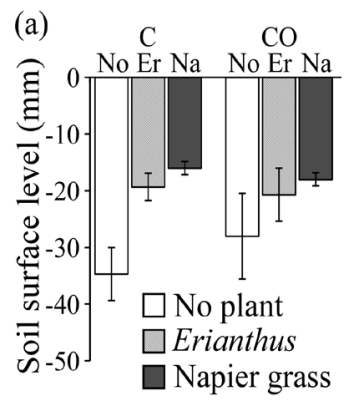

(b)

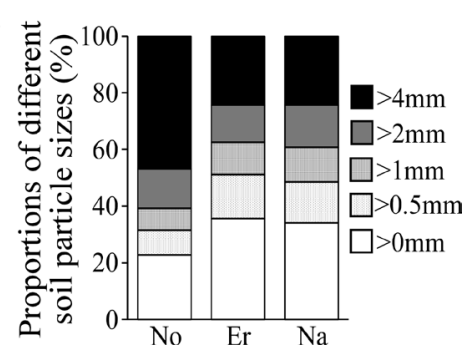

Figure 3. Soil surface level (mm) (a) and proportions of different soil particle sizes (\%) (b) measured 5 and 16 months after planting, respectively, in the second trial. No = No plant, $\mathrm{Er}=$ Erianthus, $\mathrm{Na}=$ Napier grass, $\mathrm{C}=$ chemical fertilizer alone, $\mathrm{CO}=$ chemical and organic fertilizers combined. 


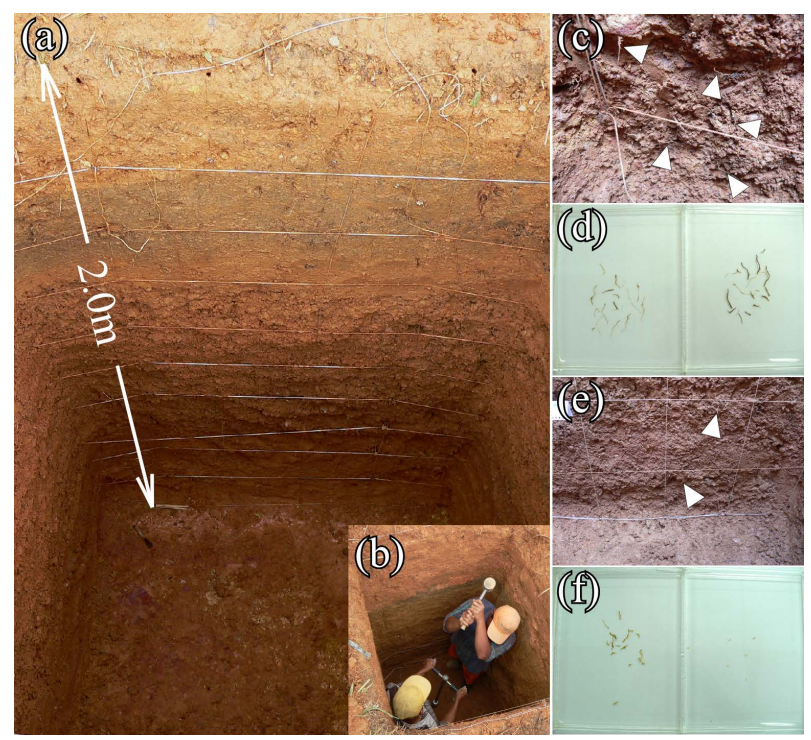

Figure 4. Root observation. A trench (1 - 2 m long $\times 1$ m wide $\times 2 \mathrm{~m}$ deep) was excavated manually (a). A soil core (50 mm diameter $\times 600 \mathrm{~mm}$ long) was sampled from the trench bottom by using a liner sampler to investigate depths of $2.0-2.6 \mathrm{~m}$ depth (b).Napier grass roots were observed in soil layers at depths of 1.8 - $2.0 \mathrm{~m}$ (c). Napier grass roots were washed out of soil layers at depths of $2.0-2.3 \mathrm{~m}$ (left) and 2.3 - $2.6 \mathrm{~m}$ (right) (d). Erianthus roots were observed in soil layers at depths of $1.6-2.0 \mathrm{~m}$ (e). Erianthus roots were washed out of soil layers at depths of $2.0-2.3 \mathrm{~m}$ (left) and $2.3-2.6 \mathrm{~m}$ (right) (f).

reported by Reubens et al. (2007) [31], the two species' proliferating shallow roots, as well as their deep roots, contribute to the reduction in soil erosion. Future studies should investigate this mechanism further.

\section{Conclusions}

Erianthus and Napier grass have a strong capability for growth even in agriculturally degraded fields where maize growth is greatly limited. At some sites, such as the abandoned mining site in this study, the environmental conditions-particularly the availability of soil water-are so harsh that even these two species fail to establish. However, when seedlings were planted rather than stem cuttings, both species established well and produced substantial amounts of shoot biomass. The application of organic fertilizer significantly improved their performances.

Both the species that were the subject of this study can convert abandoned mining sites in Lampung province into energy plant fields, provided that certain management techniques, such as the planting of seedlings and the application of chemical and organic fertilizers, are employed. The positive effects of both species on soil carbon and erosion may contribute to the sustainability of the production system and help preserve local ecosystems. Further studies are needed to investigate the economic feasibility of the production system.

\section{Acknowledgements}

This study was financially supported by the New Energy and Industrial Technology Development Organization (NEDO). We are grateful to K. Ra and T. Hayashi for the preparation of trials and to P.T. TOYOTA BIO INDONESIA for their support regarding field management and data collection.

\section{References}

[1] Boddiger, D. (2007) Boosting Biofuel Crops Could Threaten Food Security. Lancet, 370, 923-924. http://dx.doi.org/10.1016/S0140-6736(07)61427-5 
[2] Hattori, T. and Morita, S. (2010) Energy Crops for Sustainable Bioethanol Production; Which, Where and How? Plant Production Science, 13, 221-234. http://dx.doi.org/10.1626/pps.13.221

[3] Gelfand, I., Sahajpal, R., Zhang, X., Izaurralde, R.C., Gross, K.L. and Robertson, G.P. (2013) Sustainable Bioenergy Production from Marginal Lands in the US Midwest. Nature, 493, 514-517. http://dx.doi.org/10.1038/nature11811

[4] Field, C.B., Campbell, J.E. and Lobell, D.B. (2008) Biomass Energy: The Scale of the Potential Resource. Trends in Ecology \& Evolution, 23, 65-72. http://dx.doi.org/10.1016/j.tree.2007.12.001

[5] Campbell, J.E., Lobell, D.B., Genova, R.C. and Field, C.B. (2008) The Global Potential of Bioenergy on Abandoned Agriculture Lands. Environmental Science \& Technology, 42, 5791-5794. http://dx.doi.org/10.1021/es800052w

[6] Cai, X., Zhang, X. and Wang, D. (2011) Land Availability for Biofuel Production. Environmental Science \& Technology, 45, 334-339. http://dx.doi.org/10.1021/es103338e

[7] Nijsen, M., Smeets, E., Stehfest, E. and Van Vuuren, D.P. (2012) An Evaluation of the Global Potential of Bioenergy Production on Degraded Lands. GCB Bioenergy, 4, 130-147. http://dx.doi.org/10.1111/j.1757-1707.2011.01121.x

[8] Tilman, D., Hill, J. and Lehman, C. (2006) Carbon-Negative Biofuels from Low-Input High-Diversity Grassland Biomass. Science, 31, 1598-1600. http://dx.doi.org/10.1126/science.1133306

[9] Varvel, G.E., Vogel, K.P., Mitchell, R.B., Follett, R.F. and Kimble, J.M. (2008) Comparison of Corn and Switchgrass on Marginal Soils for Bioenergy. Biomass and Bioenergy, 32, 18-21. http://dx.doi.org/10.1016/j.biombioe.2007.07.003

[10] Schmer, M.R., Vogel, K.P., Mitchell, R.B. and Perrin, R.K. (2008) Net Energy of Cellulosic Ethanol from Switchgrass. Proceedings of National Academy of Sciences of the United States of America, 105, 464-469. http://dx.doi.org/10.1073/pnas.0704767105

[11] Fargione, J., Hill, J., Tilman, D., Polasky, S. and Hawthorne, P. (2008) Land Clearing and the Biofuel Carbon Debt. Science, 319, 1235-1238. http://dx.doi.org/10.1126/science.1152747

[12] Smith, S.L., Thelen, K.D. and MacDonald, S.J. (2013) Yield and Quality Analyses of Bioenergy Crops Grown on a Regulatory Brownfield. Biomass and Bioenergy, 49, 123-130. http://dx.doi.org/10.1016/j.biombioe.2012.12.017

[13] Matsumoto, N., Sano, D. and Elder, M. (2009) Biofuel Initiatives in Japan: Strategies, Policies, and Future Potential. Applied Energy, 86, S69-S76. http://dx.doi.org/10.1016/j.apenergy.2009.04.040

[14] Koizumi, T. (2013) Biofuel and Food Security in China and Japan. Renewable and Sustainable Energy Reviews, 21, 102-109. http://dx.doi.org/10.1016/j.rser.2012.12.047

[15] NEDO (New Energy and Industrial Technology Development Organization) (2013) http://www.nedo.go.jp/activities/FF_00042.html

[16] Koizumi, T. (2011) The Japanese Biofuel Program-Developments and Perspectives. Journal of Cleaner Production, 40, 57-61. http://dx.doi.org/10.1016/j.jclepro.2011.04.022

[17] Sekiya, N., Hattori, T., Shiotsu, F., Abe, J. and Morita, S. (2014) Identifying Potential Field Sites for Production of Cellulosic Energy Plants in Asia. International Journal of Agricultural and Biological Engineering, accepted.

[18] McMahon, G., Subdibjo, E.R., Aden, J., Bouzaher, A., Dore, G. and Kunanayagam, R. (2000) Mining and the Environment in Indonesia: Long-Term Trends and Repercussions of the Asian Economic Crisis. East Asia Environment and Social Development Unit, The World Bank, Washington DC.

http://commdev.org/userfiles/files/877_file_mining_and_the_environment.pdf

[19] Aspinall, C. (2001) Small-Scale Mining in Indonesia. International Institute for Environment and Development, London. http://pubs.iied.org/pdfs/G00725.pdf

[20] Prasetyo, B., Krisnayanti, B.D., Utomo, W.H. and Anderson, C.W.N. (2010) Rehabilitation of Artisanal Mining Gold Land in West Lombok, Indonesia: 2. Arbuscular mycorrhiza Status of Tailings and Surrounding Soils. Journal of Agricultural Science, 2, 202-209. http://www.ccsenet.org/journal/index.php/jas/article/download/4742/4983

[21] Hattori, T., Shiotsu, F., Doi, T. and Morita, S. (2010) Suppression of Tillering in Erianthus ravennae (L.) Beauv. Due to Drought Stress at Establishment. Plant Production Science, 13, 252-255. http://dx.doi.org/10.1626/pps.13.252

[22] Ra, K., Shiotsu, F., Abe, J. and Morita, S. (2012) Biomass Yield and Nitrogen Use Efficiency of Cellulosic Energy Crops for Ethanol Production. Biomass and Bioenergy, 37, 330-334. http://dx.doi.org/10.1016/j.biombioe.2011.12.047

[23] Fauzi, A.I., Agus, F. and Sukarman, N.K. (2011) Characterizing the Soil for Improved Nutrient Management in Selected Maize Growing Areas of Indonesia. Indonesian Journal of Agricultural Sciences, 12, 17-32. http://pustaka.litbang.deptan.go.id/publikasi/as121113.pdf

[24] Morgan, R.P.C. (2009) Soil Erosion and Conservation. John Wiley \& Sons, Hoboken.

[25] Cruse, R.M., Cruse, M.J. and Reicosky, D.C. (2010) Soil Quality Impacts of Residue Removal for Biofuel Feedstock. In: Lal, R. and Stewart, B.A., Eds., Soil Quality and Biofuel Production, CRC Press, Boca Raton, 45-62.

[26] Galdos, M.V., Cerri, C.C., Bernoux, M. and Cerri, C.E.P. (2010) Ethanol Production from Sugarcane and Soil Quality. 
In: Lal, R. and Stewart, B.A., Eds., Soil Quality and Biofuel Production, CRC Press, Boca Raton, 137-150.

[27] Lemus, R. and Lal, R. (2005) Bioenergy Crops and Carbon Sequestration. Critical Reviews in Plant Sciences, $24,1-21$. http://dx.doi.org/10.1080/07352680590910393

[28] Ma, Z., Wood, C.W. and Bransby, D.I. (2000) Soil Management Impacts on Soil Carbon Sequestration by Switchgrass. Biomass and Bioenergy, 18, 469-477. http://dx.doi.org/10.1016/S0961-9534(00)00013-1

[29] Ma, Z., Wood, C.W. and Bransby, D.I. (2000) Impacts of Soil Management on Root Characteristics of Switchgrass. Biomass and Bioenergy, 18, 105-112. http://dx.doi.org/10.1016/S0961-9534(99)00076-8

[30] Sekiya, N., Shiotsu, F., Abe, J. and Morita, S. (2013) Distribution and Quantity of Root Systems of Field-Grown Erianthus and Napier Grass. American Journal of Plant Sciences, 4, 16-22. http://dx.doi.org/10.4236/ajps.2013.412A1003

[31] Reubens, B., Poesen, J., Danjon, F, Geudens, G. and Muys, B. (2007) The Role of Fine and Coarse Roots in Shallow Slope Stability and Soil Erosion Control with a Focus on Root System Architecture: A Review. Trees, 21, 385-402. http://dx.doi.org/10.1007/s00468-007-0132-4 